Gersuni; J. physiol. Vol. 89, 1937.

6) 1949 .

18) 船石：日坐理誌, 11. 1949.

19)

Steven: \& Davis: Hearing. New York John

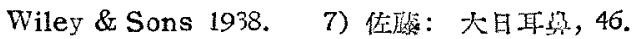
1940.

8) 玉尾：网山医会点，1943: 9) Ste- 11, 1948.

vens \& Jones: J. Acous. Soc. Amer. Vol. 10, 1939, 1940.

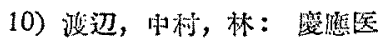
学, Vol. 22, 1942.

11）船不：女子医学研究， 19. 1949.

12)

ellaway: J. Neurophysiol.

7, 1944, 9,1946. 13) Stevens, Jones \& Lurie:

J. Acous. Soc. Amer. Vol. 12, 1940.

Galambos \& Davis: J. Neurophysiol. 6, 1943. 15) Home \& Guild, Lurie, Davis \& Derby. schire: Hearing. 1938.16$)$ Stevens \& Davis: Hearing. 1938. 17) 横屋：日生理誌，11. 学11.

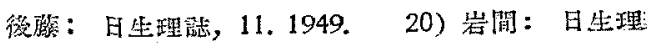
誌. 10.1948. 21) Granit: J. Neurophysiol.

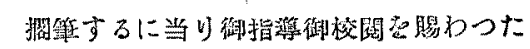

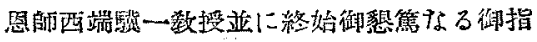

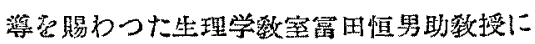

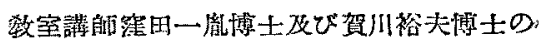

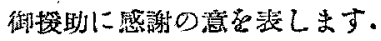

（原稿到崖 $=$ 炤租 $25.10 .14 ）$

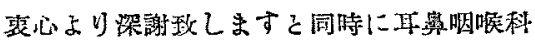

\title{
S. KATAGIRT, M.D.: EXPERIMENTAL STUDIES OF THE INFLUENCE OF ROTATION ON THE EAR
}

\section{趜轉運動の聽器に及ぼす影響に關する 實 驗 的 研 究（前篇）}

遠心徊転直挠に於ける聴器の病理組織学的研究

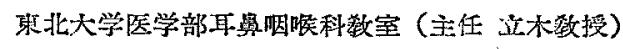

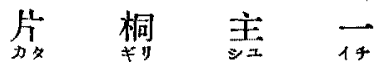

\begin{tabular}{|c|c|}
\hline \multicolumn{2}{|r|}{ 肉 } \\
\hline & 言 \\
\hline II 突 & 岉及び \\
\hline III 实 & 镮裉括 \\
\hline $\mathbf{N}$ & 按 \\
\hline$\nabla$ 絬 & 論 \\
\hline
\end{tabular}

\section{I. 綨 零}

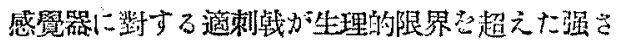
に於て作朋する時は該感覺器は機能的にのみなら市

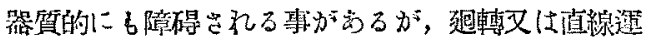

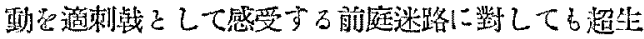

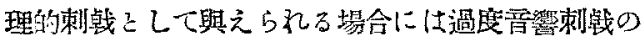
螖牛迷路に對する々同榚に前庭器感受部位に何等加 の器質的變化已招來する可能性を否定する事は出来

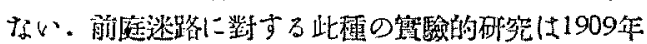

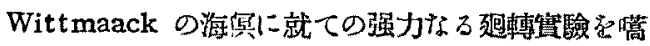
矢々 乙 de Kleyn, Magnus, Versteegh, Chilow 長谷川等にょり試みら礼た。然し其目的は耳石機能 范追求する事に岁つた，從つて其際の遠心力は耳石

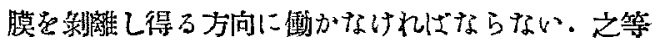

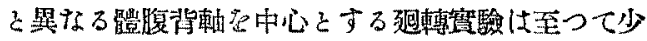
い. 䐚方柴, 林, Jonason 等の研究が放るに過ざな い. 斯樣な體長軸の方向に裳心力が作用する場合に

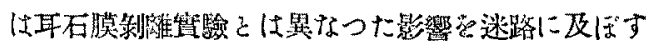

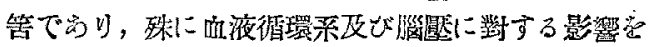

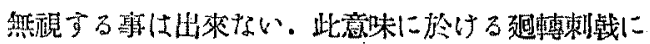

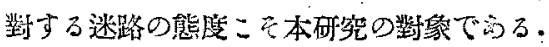

\section{II. 實験動物及び富驗方法}

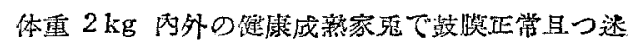

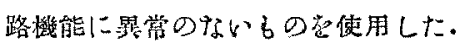




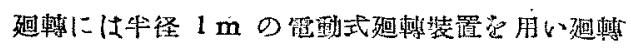

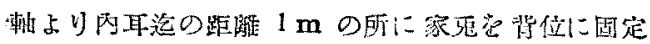

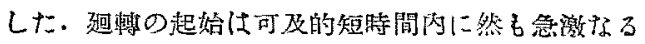

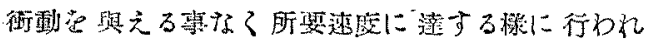

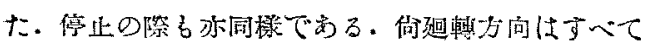

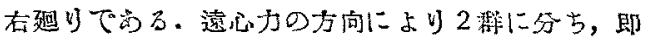

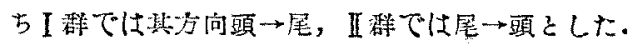

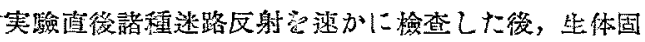
定法名行つた，固定液は Wittmaack 氏液，脂灰 夜は5\%硝酸フォルマリンを用い, Celloidinに包埋

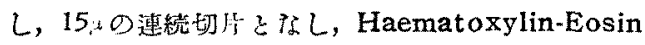
重染色㱼び Tolluidinblan 染色法尼施した。

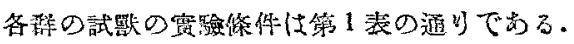

禁, 1 表

\begin{tabular}{|c|c|c|c|c|c|c|}
\hline 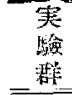 & 镇 & 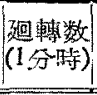 & 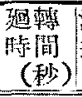 & 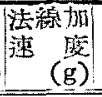 & 例 & 試橭 霍 \\
\hline \multirow{3}{*}{ I } & 1 & 96 & 60 & 10 & 3 & $26,33,35$ \\
\hline & 2 & 120 & 60 & 15 & 3 & $14,15,27$ \\
\hline & 3 & 130 & 60 & 20 & 2 & 18,19 \\
\hline \multirow{5}{*}{ II } & 1 & 96 & 30 & 10 & 1 & 37 \\
\hline & 2 & 96 & 60 & 10 & 3 & $2,4,5$ \\
\hline & 3 & 120 & 30 & 15 & 3 & $6,7,9$ \\
\hline & 4 & 120 & 60 & 15 & 2 & 10,11 \\
\hline & 5 & $130^{\circ}$ & 60 & 20 & 2 & 16,17 \\
\hline
\end{tabular}

\section{III. 蛪驗成績㯙括}

1. 外耳及び円耳

外，中耳に於ける主なる変化は出血で号る、全数

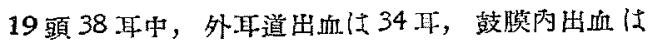

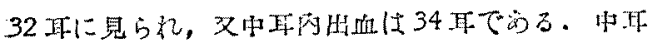
出血の好発部位は殊に前成突附近で，其他蝸牛密，

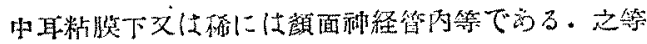

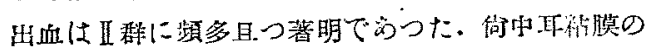

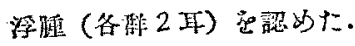

\section{2.内 两}

a. 㽍牛迷路

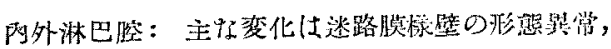

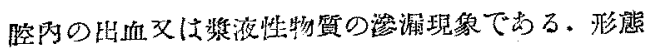
買常としてはライスネル膜（以下「ラ」膜）の站降，

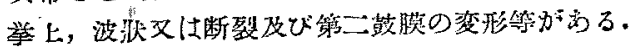

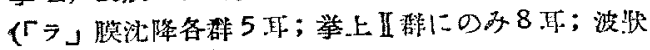

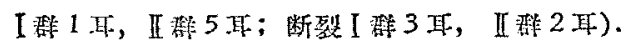

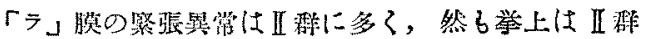
にの胃られ，沈降及び断裂はI群に多い。

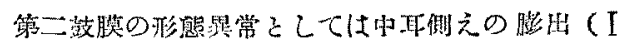

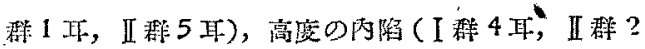

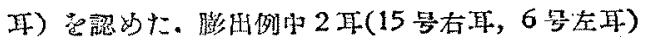
は「ラ」膜の著明な沈降を，1正(16号右耳) は其

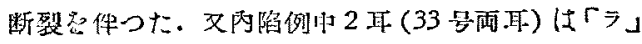

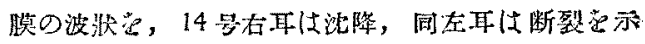
乙た。

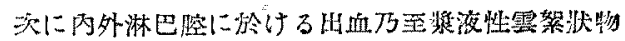

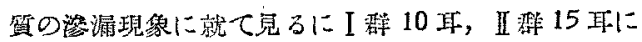

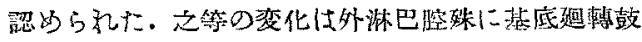
空階及び風牛導水管附に最る多く見ら亿た。其他中

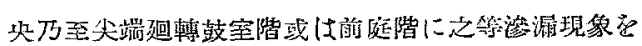

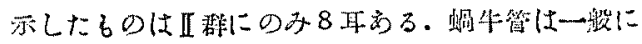

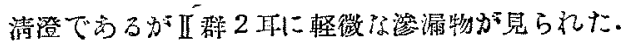

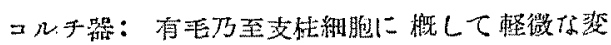
化を示したるのおるる。主なる所見は胞体及び核の

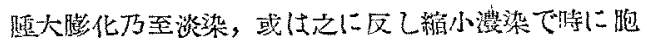

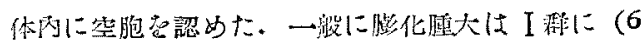

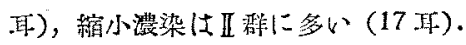

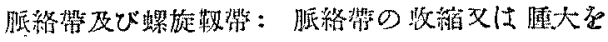

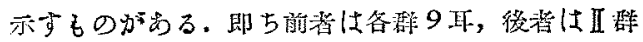

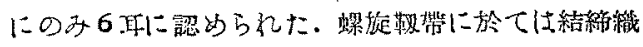

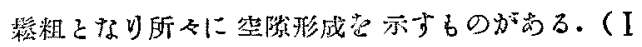

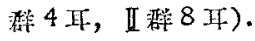

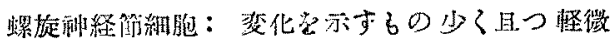

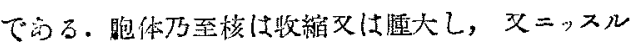

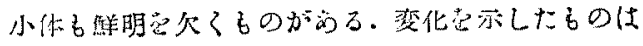
I群6.耳，II群 4 耳直で。

b. 涌庭㴹路

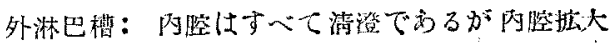

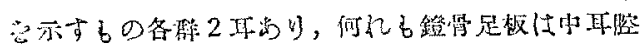

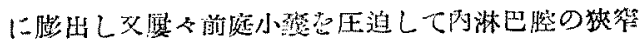

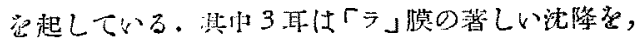

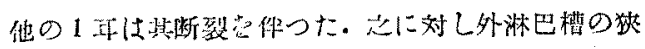
窂估开群の1耳に認的られた。

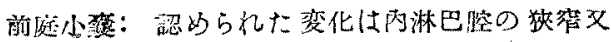

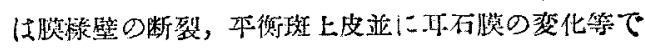
ある。 


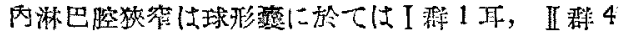

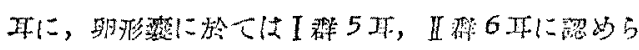

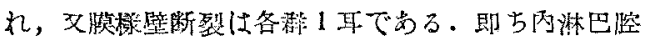

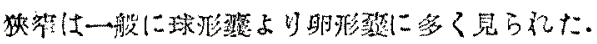

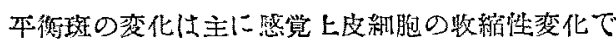

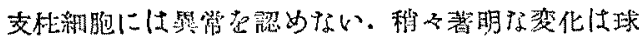

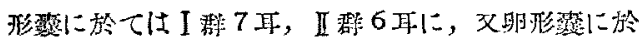
ては各释 6 耳でかる。

“次に耳石膜の変化としては耳石の減少或は耳石膜

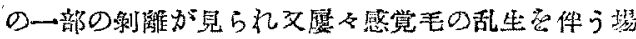

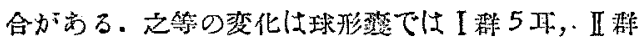

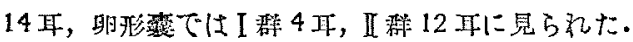

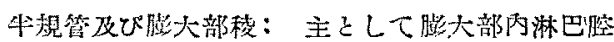
の狭究，膨大部棱感賞上皮の政縮像及び゙クプラの形

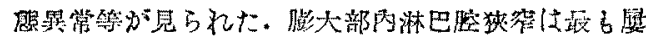

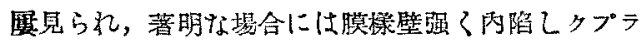

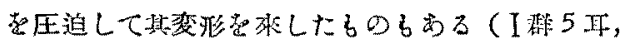

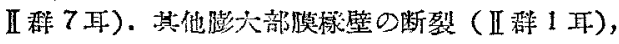

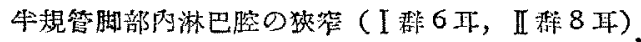

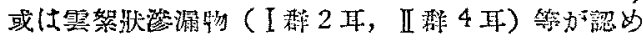
られた。

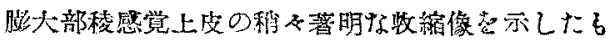

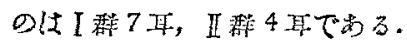

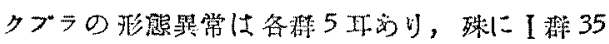
号左耳前膨大部及び II 灌 10 号右耳外膨大部に於て

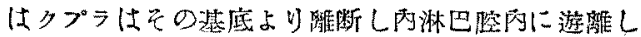

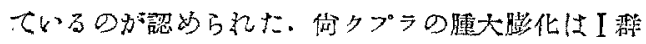
2 耳，II碓 3 耳に見られた。

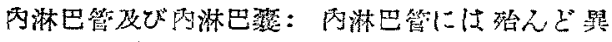

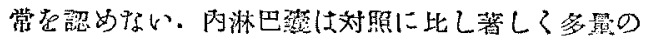

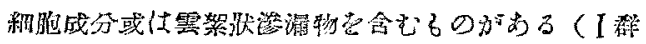

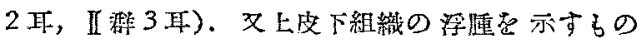
古あつた ( I磁 2 正, II 群 4 开) .

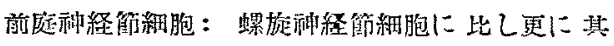

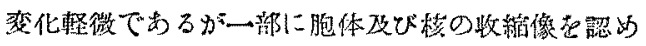
た ( 群 3 耳. II群 2 .耳).

\section{IV. 考按}

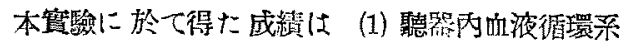
の陾䅞，特に出血，(2) 內外淋巴腔及び迷路內可動

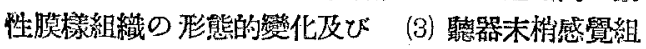
織及び神經諸要素の變化の3項に装約される。
1. 血液循摆柔㜔䅞（特に出血に裁て）

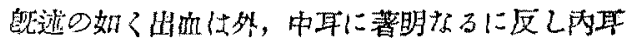

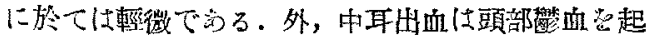

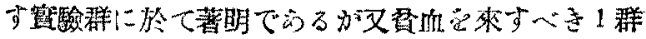
にも見られな點は林の成樍と同栐でらる。留外，中 耳出血は血管に富主僛組織が硬固な骨組織に挍する 部位に好稃し，從つて血管破綻性出血で司る。之に

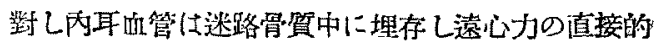
破壤作用已蒙り難了，又急唀なる国轉に際しての血

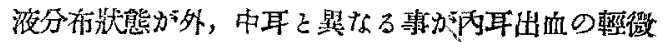
且つ稀なる因であろう，遠心迥轉による內耳出血は Wit tmaack, 三井等の言う如 了濾出性出血 看做

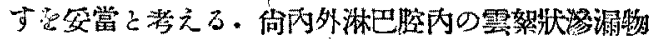
の存在亏亦血液循環暲碍心由來する戀化と考元度

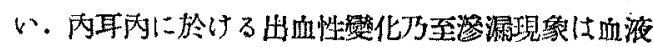

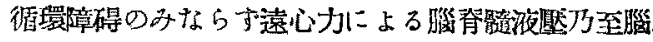
国の變動る办之に關與するものと思われる。

\section{2. 內外淋巴䧑及び膜樣組織の形態照常}

蝸牛迷路に於ては「ラ」荧及び管二鼓膜に，前庭

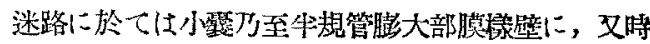

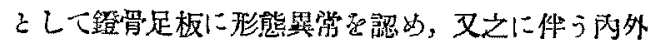
淋巴腔の變形が見られたが之等の籫化は何れる内外 淋巴液媐の本衡破䅱に因るるのである。「テ」膜の

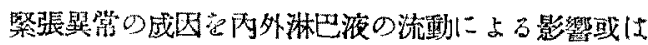

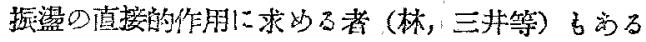

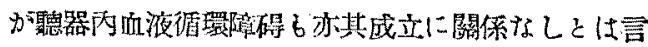

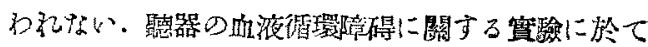

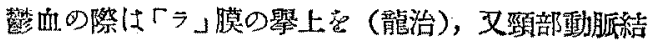

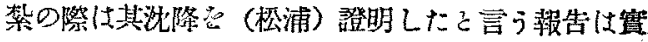

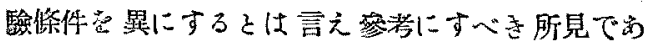

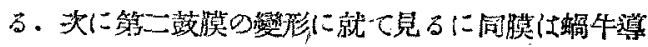

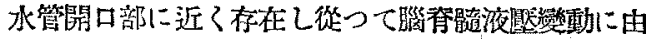
來する外淋巴液郹の影響を感受し易い位置にあると 共に抬方中耳よりする影響る受け易いるのを考元ら れる。從つて同膜の形態變化は迷路液の過度な流動

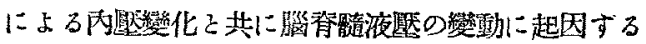
るのであらう・本㖬驗に於て膜膨出例に「ラ」膜沈

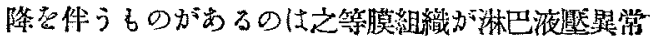
に影響される事走示すものでする，佮前庭迷路に於

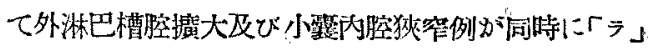
膜の著しい沈降を件つだ所見は迷路外淋巴液旺祭常 


\section{片 桐 諭交附圖}

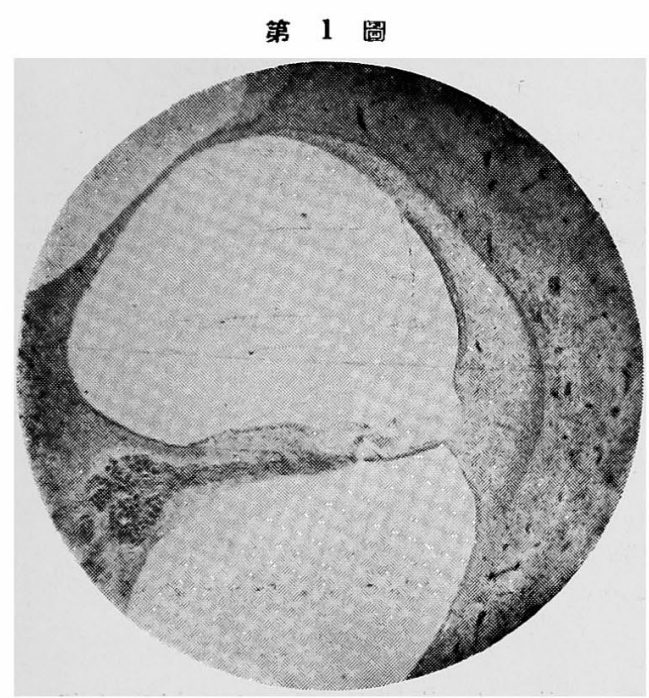

第1 图 第4 号動物 左开蝸牛迷路 ラ1

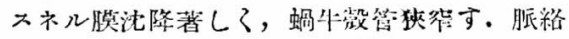
帶に稻々收綃す。 $(10 \times 8)$ [Zeis〕

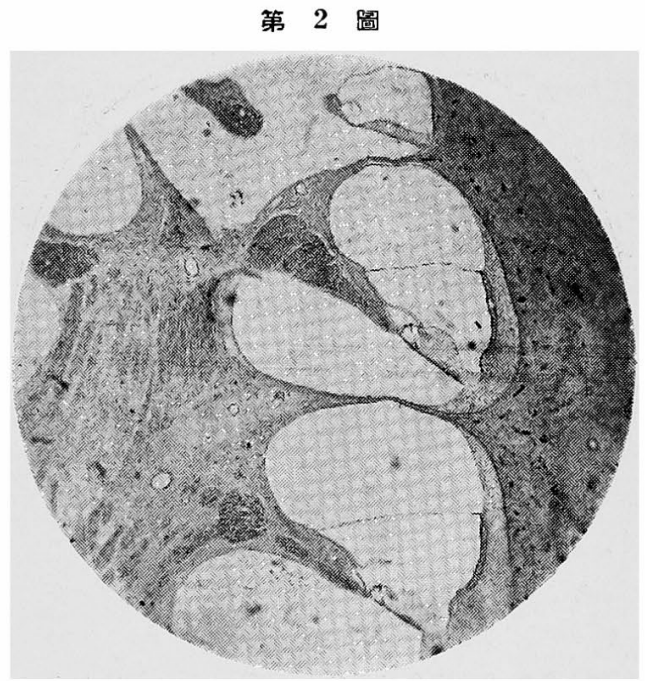

第 2 図 第7 号動物 右开蝙牛迷路 ラ1

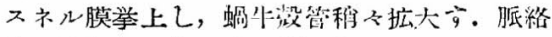
帶血管は搪張总示す。 $(5 \times 8)$
第 3 圆

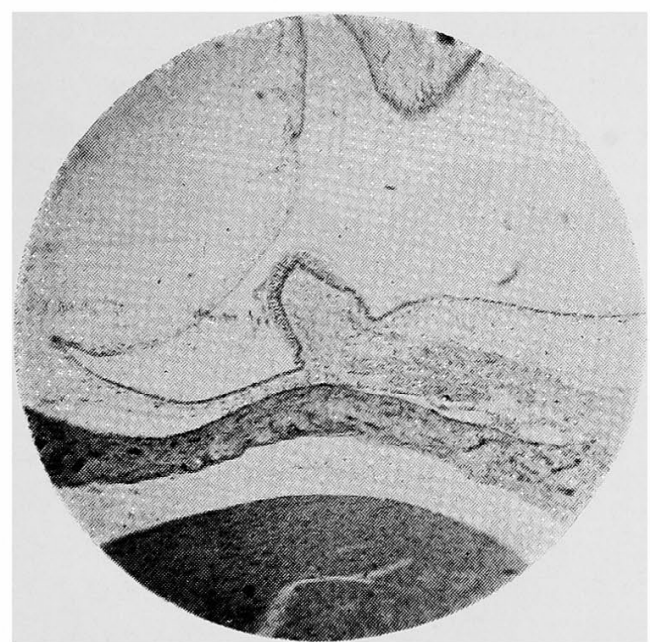

第3図 第15号動物外倒膨大部内淋巴腔

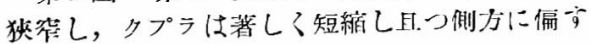
$(10.8)$

\section{第 4 圖}

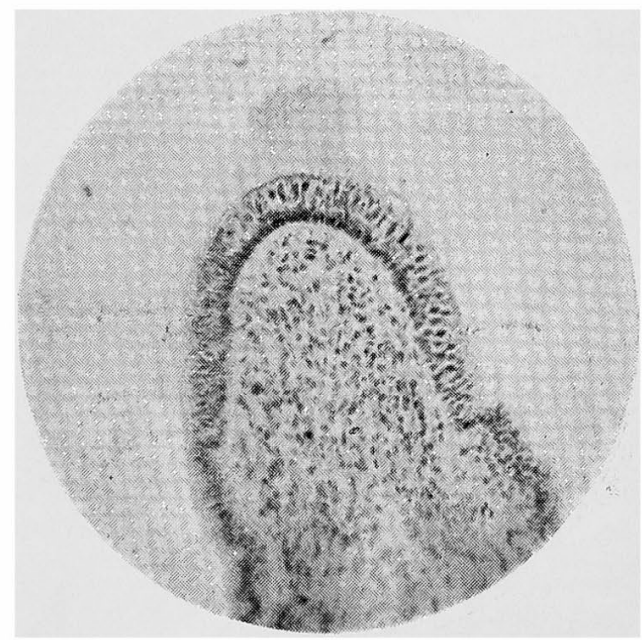

第 4 図 第14号動物 右耳外側膨大部 㯖櫛感覚上皮の收縮像它示与。胞体の收綃， 核の縮小，澧染总認妙，クプラ俚著しく短 縮与。 
第 5 圖

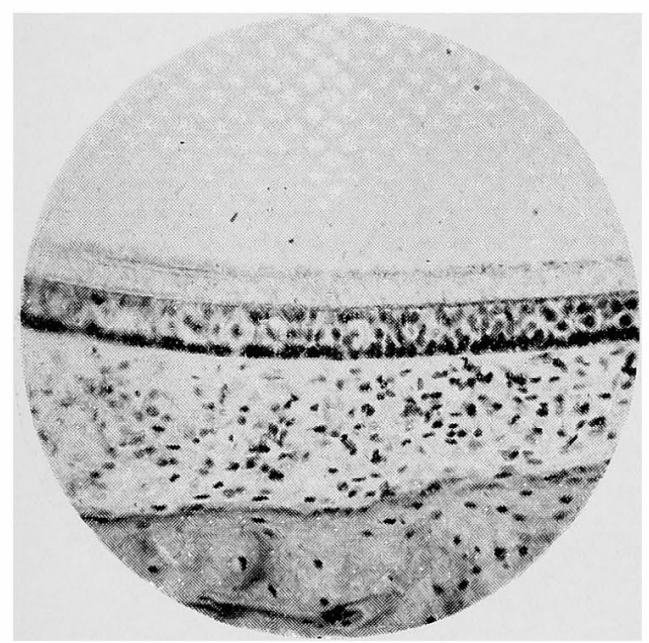

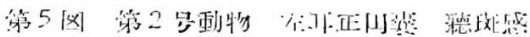

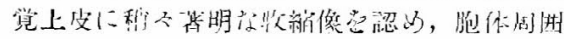

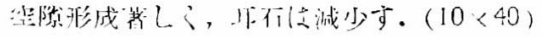

第 6 圆

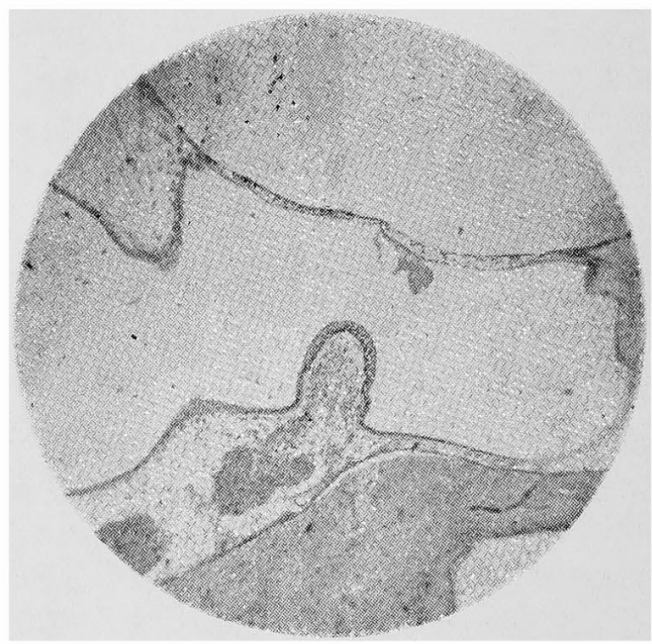

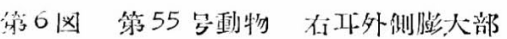

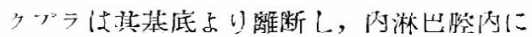

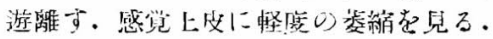
$\left(\begin{array}{ll}10 & 8\end{array}\right)$

\section{第 7 圖}

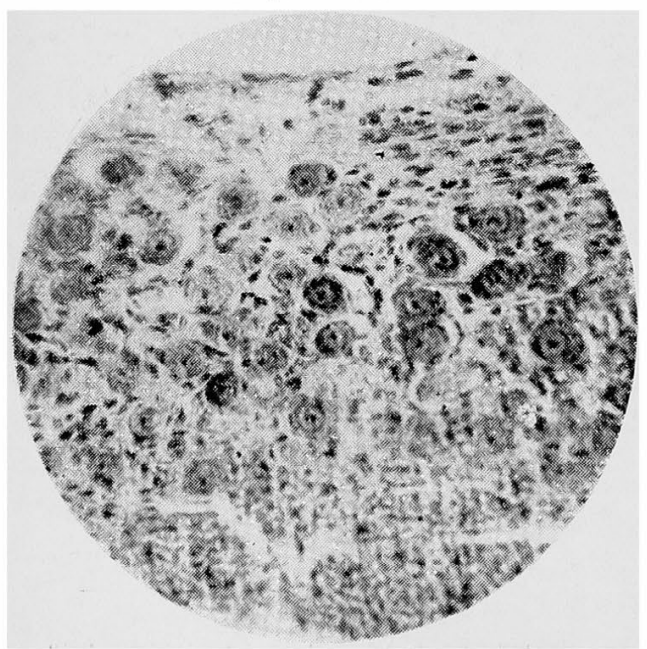

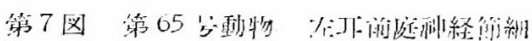

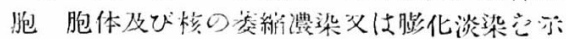

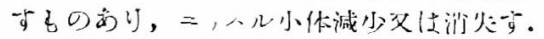
$(10 \times 40)$

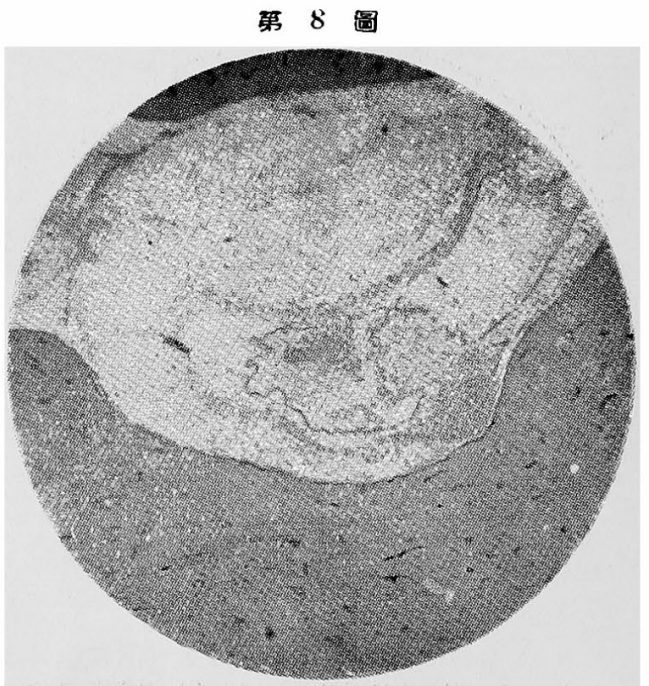

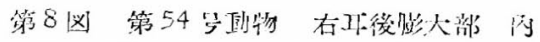

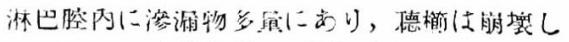

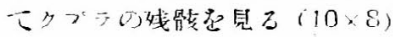


特に卉進意味するものさ言えよう。

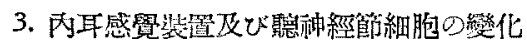

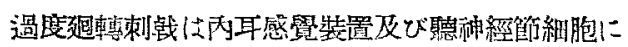

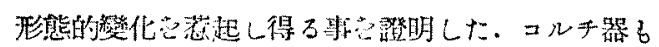

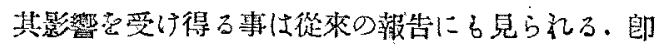

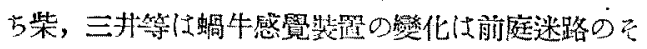

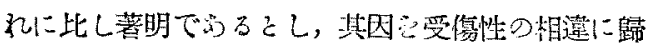
した. 之に反し Witt maack は螖牛迷路は前庭迷路

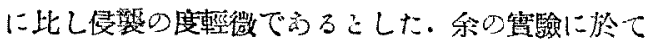

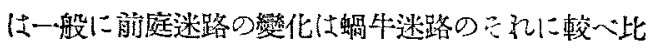

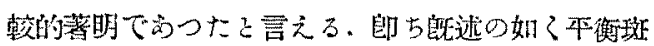
及ど膨大部稜の感覺細胞蕜に耳石膜及びダプラに形 態的紸化が證明きれた，之等前庭迷路感覺裝置の所 見ここ本筧驗の特徽でちる。其一部に感鱟上皮に所

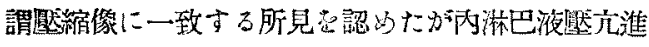

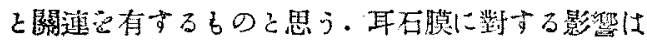
同膜制離学目的とする迎轉筫驗の場合已同列視し得 はいのは當然であるが，耳石膜に對する遠心作用の

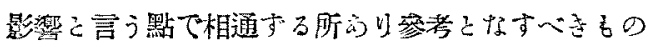

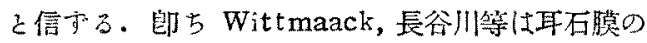

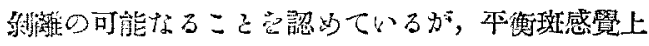

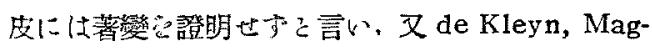

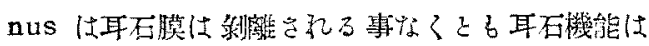

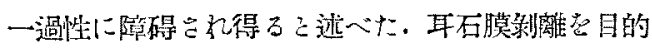

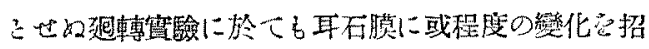

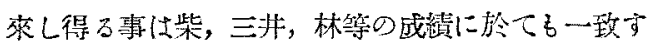
る所である.之等耳石缸の變化は耳石の比重大なる 第好遠心力口作用总受け易了過度の迷路震温作用6

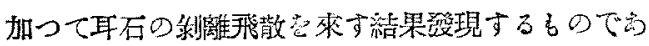
らう・次にタプラの形態的變化，洙に其基底よりの

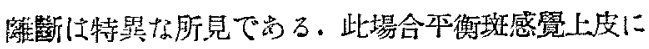

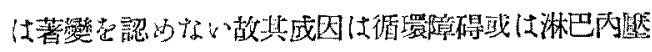
の變動では譛明されれい，徒つて遠心力の直接的 作用によるるのを考うべきでかるう，長欲川はプ

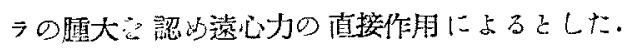

Wittmaack, Chilow 等は遠心力はタプラに器貿的 障碍觉起し得ないて述へているが柴，三井は膨大部

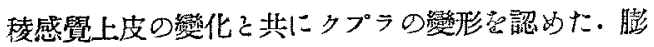
大部稜は超轉渾動の感受部位であるが通刺钱々踓る

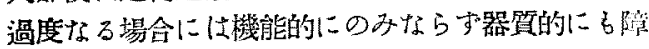

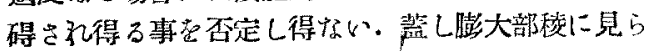

$7 \sim 17$

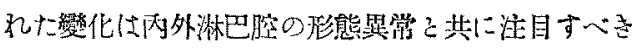
所見でらる。

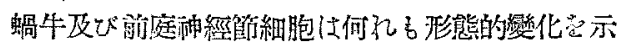

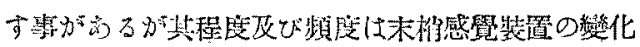
に此し一般に輕微でか叮然る節細胞に變化宫示す場 合はすへて其末梢感睍裝置る亦侵されているる言う

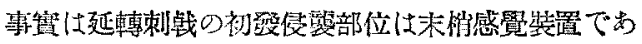
る事意味するるのでらる。

\section{脈絡帶及び螺旋勒帶の變化}

內淋巴液生成部位と看做される胍絡帶, 及び螺旋

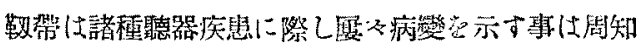
の事質でかる，殊に内淋巴液分泌乃主血液调環障碍

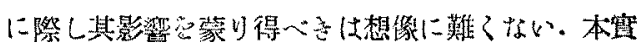
驗に於てII群に血管撗張を共に「ラ」膜の擧上㤂示 するのさ認妙たが此所見认胍絡帶の队洣已液生成機 能に閶連市るるのとして注目すの告るのと思う。

內淋巴犂の變化

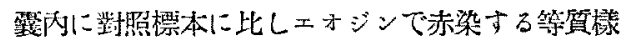

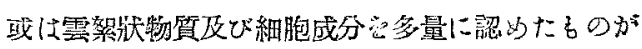

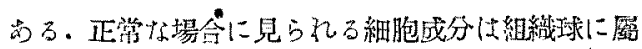

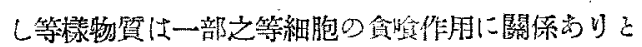
されているが，本筫騟に於て多量に證明されたのは

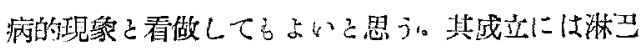

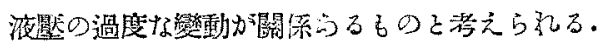

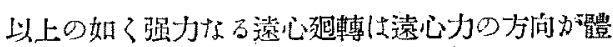
長軸に一致する場合に於てる兽器迷路に形態的變化

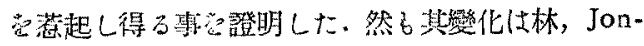

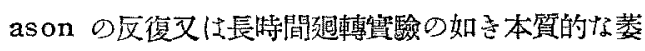

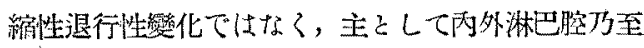

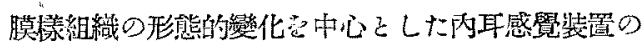
形態異常で放ると言う事が出來る。

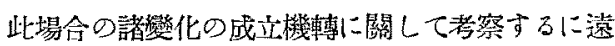

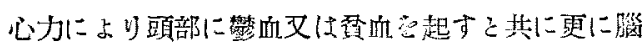

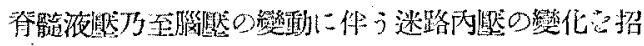

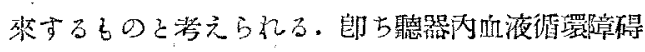
の結果並に遠心力口南接的作用与加わり，外，中耳

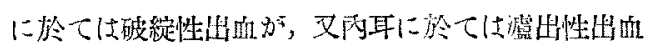

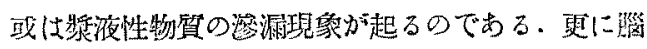

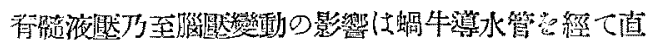

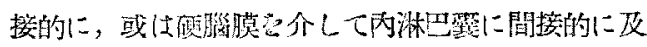




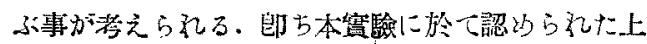

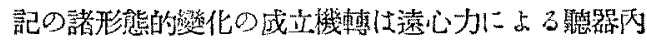

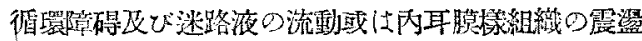

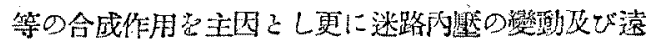

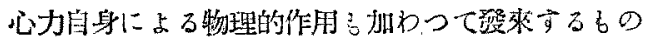

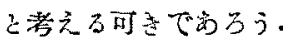

\section{V. 結論}

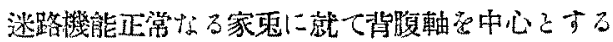

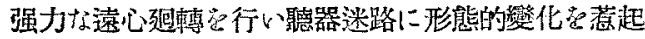
し得る事る證明した。其主なる成績は次の通りでか る.

1.外耳改び 中耳に於ては主こして出血が胃られ t.

2.内耳に於てに出们性變化は輕微でちつて主要な

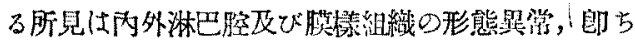
「ラ」膜，第二鼓膜，外淋巴槽，前庭小垔及び牛規

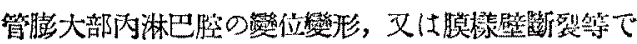
点万。

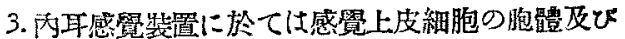

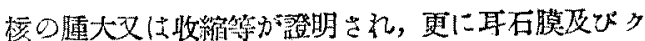
ブラの變化を走したるのが少くない。

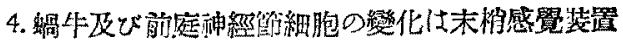

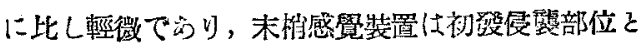
考えられる。

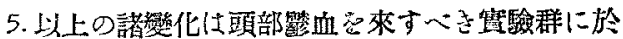
て一般に頻多且つ高度である。

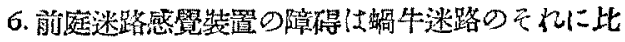

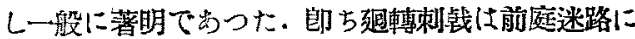

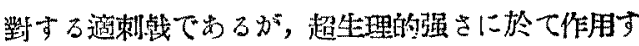

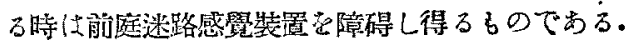

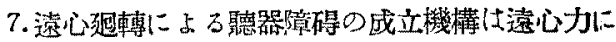

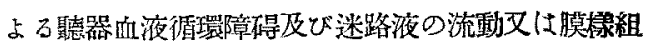

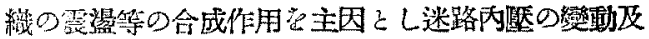
び遙心力自身の物理的作用も加わつて起るるのを考 えられる。

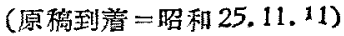

S. HAYASHI, M.D.: STATISTIC STUDY OF MASTOID CELL DEVELOPMENT IN CASES OF CHRONIC OTITIS MEDIA, AS OBSERVED IN X-RAY PICTURES.

慢性中耳炎の側頭骨含氣蜂笨の「レj線像に 依了統計的研究

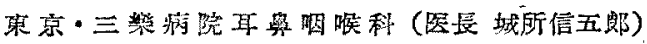

医学士 林

【敢新)

第4 项 慢监中耳资「レ」線像に於りる

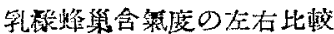

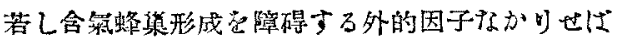

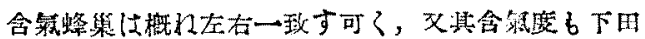

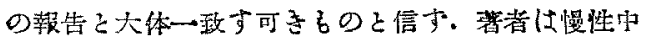

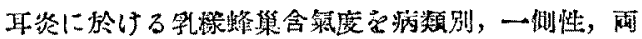
狮性のるのに分類して左右を比較考察せんるす。

[A] 慢性固有鼓空化胚症に於ける 左右一形度 (データ省略)

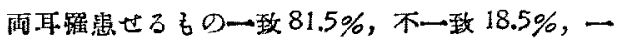

过紫

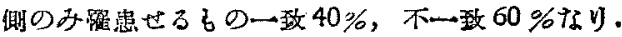

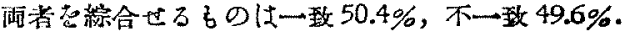

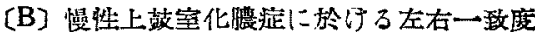
(データ省略)

雨耳霍患さ36の一致 $84.2 \%$ ，不一致 $15.8 \%$ ，一

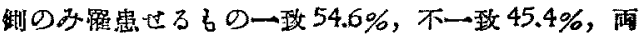

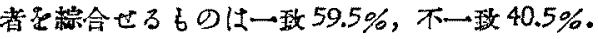

(C) 䱇珠症に於ける左右一致度 (データ省略)

雨耳羅患さるちの一致 $96.4 \%$ ，不一政 $3.6 \% ， 一$ 